\title{
ECONOMIC ASYMMETRIES OF PRODUCTION IN THE AGRICULTURAL SECTOR
}

\author{
V. Blazheva* \\ Department of Agricultural Economics, Dimitar A. Tsenov Academy of Economics, \\ Svishtov, Bulgaria
}

\begin{abstract}
The development of efficient and sustainable agriculture requires its permanent transformation. In this aspect, various methods of growing plants and breeding animals are applied to optimize production. These methods are distinguished mainly as: traditional (conventional) production, organic production, production of genetically modified organisms. From this standpoint, attention is drawn to: covering the widest possible range of terms used to characterize the variety of plant growing and animal breeding methods; a brief overview of the established in theory and practice modern methods of plant growing and animal breeding; delimiting the notion of biological - as a vital process, regardless of the plants and animals production technology (including the use of organic fertilizers; preparations containing live bacteria; treated seeds with live bacteria, etc.).The methods of the present study are scientific research methods: induction and deduction method, retrospective analysis and others; illustrative methods - schemes, figures and others. Regarding the expected results, this article focuses on highlighting the social, economic and environmental aspects of production of plant and animal products. Production in the agricultural sector must be aimed at recovery of residues and waste from crop and livestock production in harmony with the environment.
\end{abstract}

Key words: agrarian sector, agrarian policy, agriculture, traditional (conventional) production, organic production, production of genetically modified organisms.

\section{INTRODUCTION}

The significance of arable land as a productive resource for agriculture determines the necessity of control over its fertility (1).

Fertility is a complex, dynamic ability of the soil to create conditions for plant development throughout the growing season. The soil has this feature as a natural essence, which can be characterized as natural fertility.

With the advent of human society, it affects the soil in order to increase soil fertility. This new fertility is an artificial, acquired fertility .

*Correspondence to: Violeta Blazheva, Dimitar A. Tsenov Academy of Economics, Svishtov, Bulgaria, Department of Agricultural Economics, "Em. Chakarov" Street, 5250 Svishtov, E-mail:v.blazheva@uni-svishtov.bg, Phone: +35963166262
In practice, the two types of fertility are interrelated and are characterized as economic fertility.

Fertility depends on two groups of factors: Objective factors - the most significant of them are: the structure of the soil and natural and climatic conditions.

The subjective factors that affect soil fertility are related to human intervention. More significant are: fertilization with natural and artificial fertilizers; weed and pest control; irrigation; protection of losses from already obtained products; yield programming.

For centuries, the farmer has been convinced that ploughing is necessary for growing crops. However, principle of "refusal to cultivate" is fundamental in natural agriculture. 
People disturb the natural life of habitat. Left without intervention, the soil maintains its fertility in a natural way, in parallel with the development cycle of plants and animals.

The nature, left untouched, is in perfect balance. Harmful insects and plant diseases have always existed, but they do not spread in nature to such an extent that requires the use of chemicals.

\section{CONCEPTUAL FOUNDATION OF PRODUCTION IN THE AGRICULTURAL SECTOR}

Various methods of plants growing and animal breeding are applied in the production. These methods are distinguished mainly as: traditional (conventional) production, organic production, production of genetically modified organisms.

The above-mentioned does not exhaust the variety of concepts and definitions for their classification. In this sense, in theory and practice some definitions are gaining popularity.

These definitions are: natural farming, organic farming, ecological farming, mountain farming, biodynamic farming, conservation farming, environmentally friendly farming, sparing farming, soilless farming, sustainable farming, alternative farming, intensive farming, precision farming, digital farming, intelligent farming, innovative farming, social farming, etc.

In certain situations, used as synonyms, interdependent, casual-consequence or mutually exclusive productions, they suggest the application of technologies perceived as effective.

The similarities and differences are related to the way of organization of plant growing and animal breeding.

It is believed that with the technicalization and chemicalization of the agricultural sector in the last century, the reproductive capabilities of plants and animals have been degenerated. This is perceived as a turning point for conventional agriculture, in which it is considered, the maximum results have been achieved.

With the soil depletion - a prerequisite for growing plants respectively animals, production in unison with nature is
BLAZHEVA $V$.

necessary, regardless of the terminology of the technology - whether it is sustainable, sparing, ecological, etc., the personal responsibility for soil protection as a resource for production in balance with the economic benefit is essential.

The pointed distinction of fertility as natural and artificial, respectively economical, gives grounds for the opinion that any production (plant and animal) is biological from the point of view of the life processes that take place in the cultivation of plants and animal breeding as a species. That is why we consider that the productions in the agricultural sector can be conditionally differentiated as: natural, artificial, resp. economical.

The use of the term "biological" has a misleading character, as every process in the development of plants and animals is vital, i.e. biological. The whole life is a constant process of transformation, a cycle of repetitive processes, which is interrupted again and again.

\section{CONTEMPORARY METHODS FOR GROWING PLANTS AND BREEDING ANIMALS}

In this paragraph, we will consider some of the contemporary methods of growing plants and breeding animals.

Permaculture, the so-called perpetual agriculture - eternal activity, is an applied science for the design of human habitats and productive agricultural systems, resembling the most natural ones. It is based on ecological and biological principles to maximize benefits and minimize efforts. The results of each process are a resource for another process - Scheme 1.

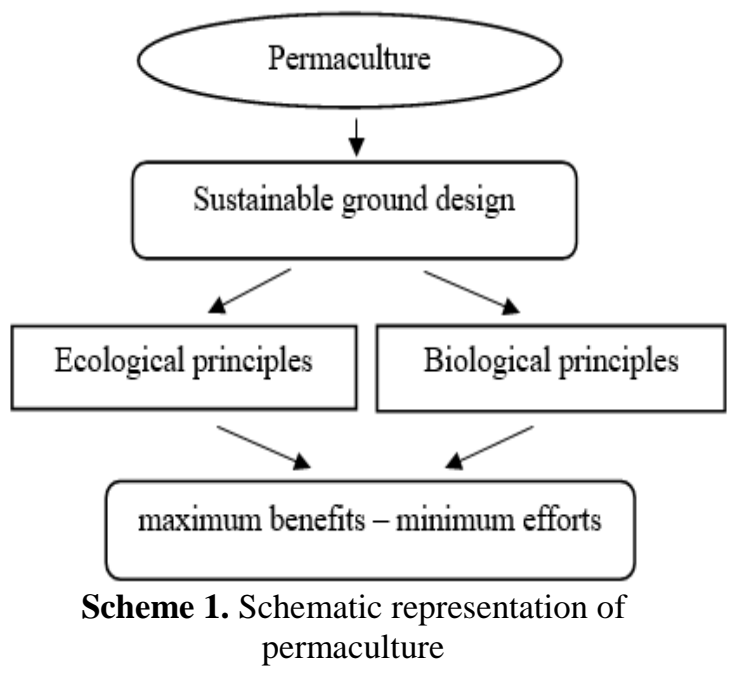


(1)

Biodynamic agriculture is an approach in agriculture based on the concept of life. It is presented as the first biological system (alternative to traditional technologies)
BLAZHEVA $V$.

without the use of chemical elements. Manure is used to cover the crops. In this aspect, biodynamic agriculture has similar practices to permaculture (2) - Figure 1.

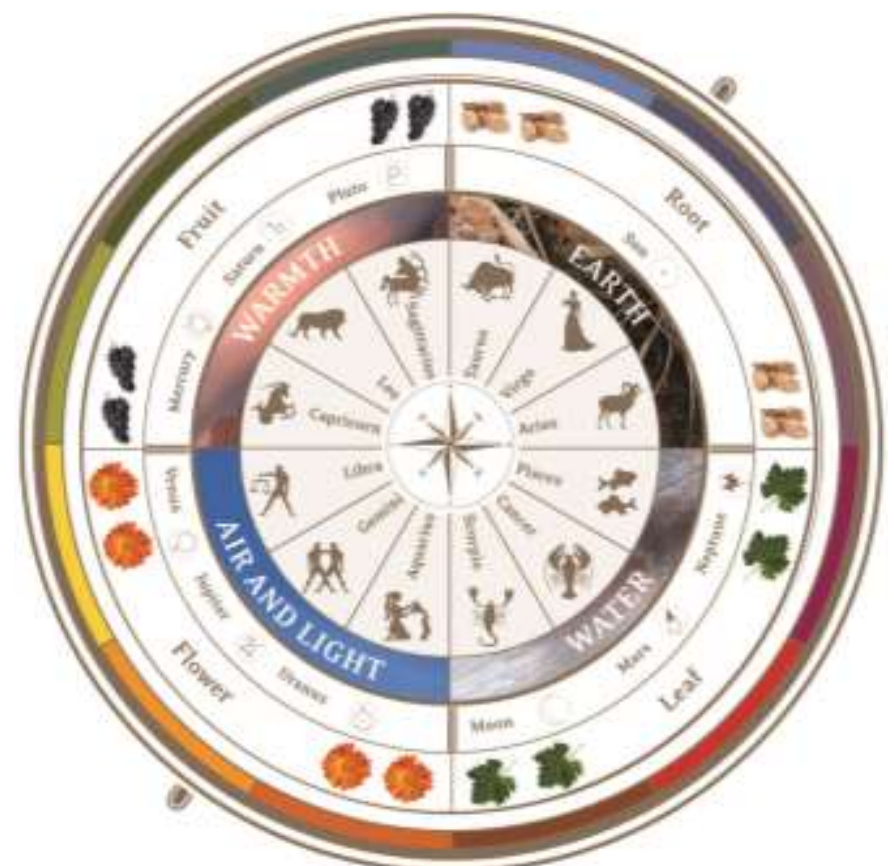

Figure 1. Biodinamic agriculture

Source: http://agritech.tnau.ac.in/

(2)

Simplified organic agriculture is formed from biodynamic agriculture, both of which pursue the same goals (3).

Sustainable agriculture is a trend in agriculture based on three main objectives -
Scheme 2. The idea of sustainability is based on the idea that current needs of humanity must be met without compromising the ability of future generations to meet future needs.

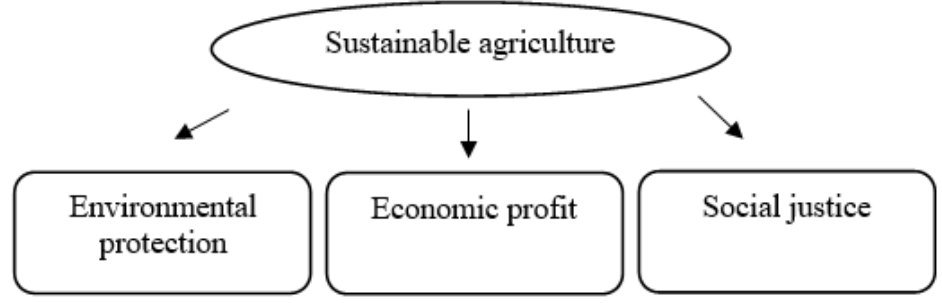

Scheme 2. Schematic representation of sustainable agriculture

(3)

Conservation agriculture - a technology in which deep tillage is replaced by building a biological soil ecosystem. Soil fertility is regulated by soil management, shallow tillage and weed control (5).

With the development of sustainable biotechnology - plants grown by using new technologies such as gene editing and in vitro mutagenesis, it is claimed that the production of genetically modified organisms is a thing of the past (6).
For organic products - defined as "useful for nature and useful for human being" there are no convincing facts. Farmers use "safe" pesticides beyond the permissible limits set by the health authorities. European policy on organic products allows the use of synthetic pesticides to compensate for "local climatic, cultural and structural events" and even after their usage the production can again be categorized as "organic" (7). It is also allowed to use untreated manure for fertilization, which can be from livestock 
farms, where animals are fed en masse with antibiotics (8).

From this standpoint, we consider that organic production falls within the boundaries of traditional agriculture. The production of organic products in "pure" form is almost impossible, on the one hand to feed the population, and on the other - it's (none) coexistence with genetically modified organisms with a tolerance threshold of $0.9 \%$ at European level.
BLAZHEVA $V$.

In intelligent agriculture or the future agriculture, the so-called Third Green Revolution driving force is the IoT - the concept of connected intelligent machines and sensors, integrated into farms to make data-driven and data-activated agricultural processes (9) - Figure 2.

Precision agriculture makes growing of plants and breeding of animals more controlled and accurate. It allows decisions to be made per square meter or even per plant /animal - location, well-being and health.

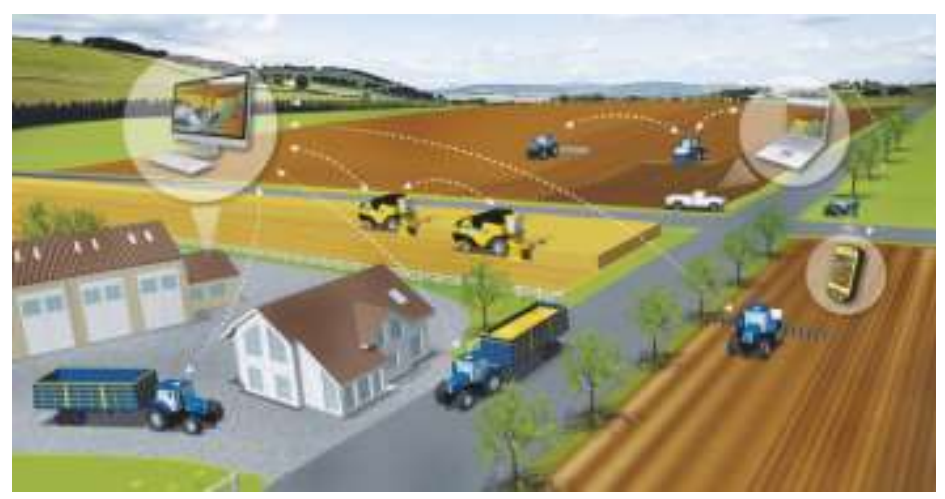

Figure 2. Intelligent Agriculture

Source: https://agriculture.interagri.bg/

The potential of the intelligent network of sensors, actuators, cameras, robots, drones and other connected devices bring an unprecedented level of control and authomated decision-making and make it possible to build a permanent innovative ecosystem - Figure 3.

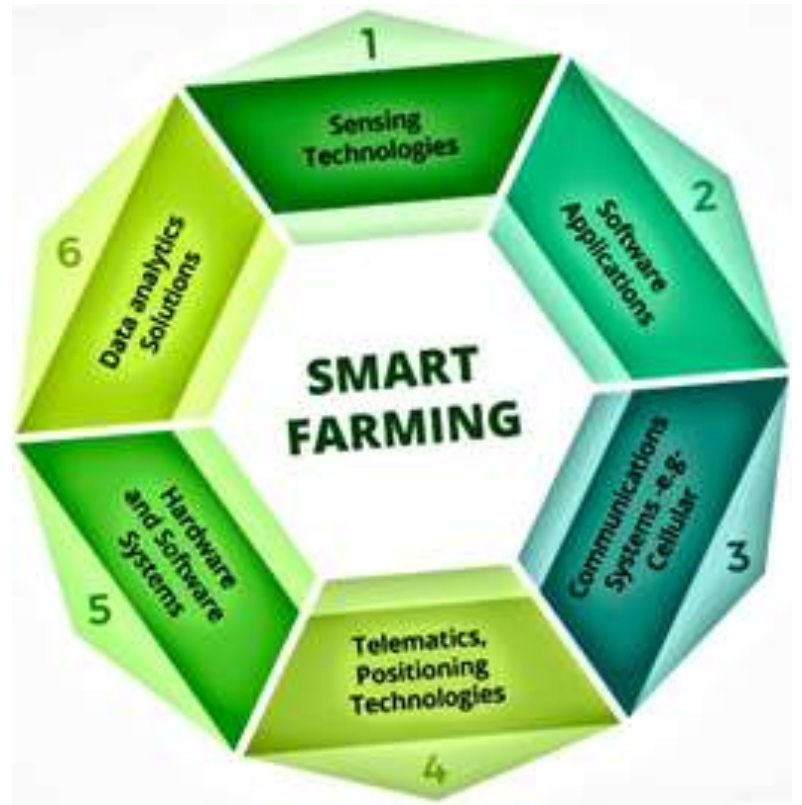

Figure 3. Smart Farming

Source: https://bg.themeridiancafe.com/

Circular production is also known as closed-loop agriculture: an agricultural method in harmony with nature, not against it - Figure 4. 
(6)

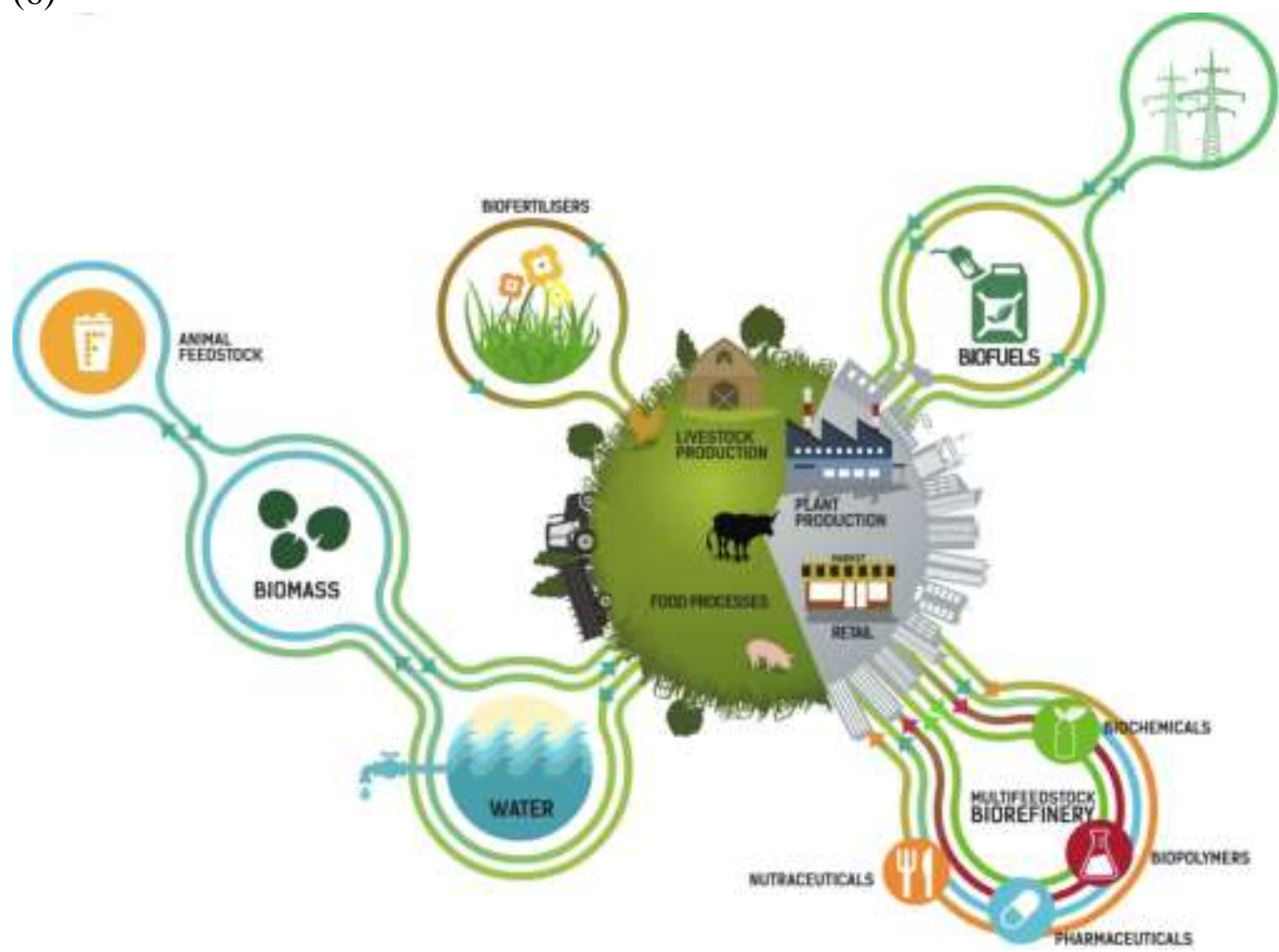

Figure 4. Circular agriculture model

Source: https://agri.bg/novini/predstavyat-modeli-na-kragovata-ikonomika-v-zemedelieto, 12.06.2020

Residual products from one chain are raw material for another (10). The focus of circular agriculture is on reducing the use of raw materials, not on mass production at the lowest possible price (11).

At European level, the circular economy is expected to increase global competitiveness, to stimulate sustainable economic growth and to create new jobs.

The term hydroponics means an agricultural practice aimed at growing crops in a soilless substrate. For their growth, a nutrient solution of natural elements necessary for the growth of plants in the soil is used. Derivatives of hydroponics are aeroponics and aquaponics.

\section{CONCLUSION}

Declaring against intensive food production, sometimes, new approaches are based on traditional knowledge from the time before industrialization and mechanization. Turning to traditions does not mean going back in time to the first farms. After the revolutions in plant growing and genetics, the Third Green Revolution "conquered" the agricultural sector based on the combined application of information and communication technologies such as precision equipment, the Internet of Things, sensors and actuators, geopositioning systems, Big data, drones, robotics, etc.

Contemporary technologies such as robots, drones, satellites and electronic detectors have their place in the sustainable agriculture of the future.

Each farm is considered as an organism with its own individuality.

There is a need for a conscious change towards the production of the cleanest possible food in balance with nature and economic interests.

With an emphasis on avoiding the problem of the negative impact on the human body of the products of contemporary agriculture, all the presented methods for growing plants and breeding animals are reduced to imposing their own concepts, innovative approaches and ideologies, which have their supporters and opponents.

The fact is that plants growing and animals breeding, regardless of the method, is eternal activity, but there is no real, publicly available data on the scale of production of plants and animals from permaculture, biodynamic, hydroponics, 
etc., in order to comment their scale and relative share in the total; solvency, awareness and willingness to consume by consumers and other factors.

\section{REFERENCES}

1. Gerganov, G. V. Blazheva \& other. Ikonomika na agrarnoto predriyatie, AI "Tsenov", Svishtov, 2010

2. http://zasei.me/index.php?topic $=91.0$

3. https://back2nature.rocks/

4. https://agroclub.bg/news/

5. https://euractiv.bg/section/политика/ne ws/интензивно-земеделие-гмо-иданък-върх/

6. https://www.puls.bg/eko-sreda-c-43/mitli-e-poleznostta-na-organichnozemedelie-n-15262

7. Petrova, S. Justification of the structuring of the assortment of agricultural products (in bulgarian). Proceedings of the Jubilee Scientific and
BLAZHEVA $V$.

Practical Conference with International Participation "National Agrarian Sector an Element of European Agricultural Regions in the Europe 2020 Strategy", Tom I, AI "Tsenov", Svishtov, p. 267272, 2014.

8. https://bg.themeridiancafe.com/recipe/s mart-farming-or-the-future-ofagriculture-c9c44c/

9. https://www.bgfermer.bg/Article/837989

10. Petrova, S. Study of the changes in the structure of the assortment of agricultural products (in bulgarian). Sbornik dokladi ot Krygla masa "Obshtata selskostopanska politika na Evropeiskia syiuz I agrobiznesa v Republika Bylgaria - ikonomicheski I pravni problemi, AI "Tsenov", Svishtov, p. 113-118, 2016.

11. http://cap.europe.bg/bg/node/361 
BLAZHEVA $V$. 